Forthcoming in Human Rights in India (Routeledge Human Rights Series) edited by Satvinder Juss.

\title{
Acid Attacks in India: The Case for State and Corporate Accountability for Gender- Based Crimes
}

\section{Sital Kalantry and Jocelyn Getgen Kestenbaum*}

\section{Introduction}

Acid attacks occur in many countries, including Uganda, ${ }^{1}$ Ethiopia, ${ }^{2}$ Colombia, ${ }^{3}$ the United States, ${ }^{4}$ India ${ }^{5}$ and many other South Asian countries. ${ }^{6}$ India has high incidence

*The authors would like to thank Sumridhi Kaur for her excellent research assistance for this chapter.

${ }^{1}$ See Bonnie Allen, Acid Attacks on the Rise in Uganda, PRI (Jul. 20, 2011), http://www.pri.org/stories/2011-07-20/acid-attacks-rise-uganda; see also Amy Fallon, Meet the Inspiring Acid Attack Survivors Who are Pushing to Change Uganda's Laws, TAKEPART (Mar. 1, 2016), http://www.takepart.com/article/2016/03/01/uganda-acid; Acid Survivors' Foundation Uganda, Acid Violence in Uganda: A Situational Analysis (2011), https://www.asti.org.uk/assets/uganda_asfu_situational_analysis_report_final_nov2011_1.pdf. 2 See, e.g., Jon Sharman, Ethiopian Woman's Mouth 'Melted Shut in Horrific Acid Attack by Husband,' INDEPENDENT (Sept. 1, 2017), https:/ / www.independent.co.uk/news/world/africa/ethiopiawoman-acid-attack-mouth-melted-shut-husband-atsede-nigussiem-tigray-area-a7924286.html; see also Amber Henshaw, Acid Attack on Woman Shocks Ethiopia, BBC News (Mar. 28, 2007), http://news.bbc.co.uk/2/hi/africa/6498641.stm.

${ }^{3}$ See Simeon Tegel, Colombia Cracks Down on Horrific Wave of Acid Attacks Against Women, USA TODAY (Jan. 20, 2016), http://www.usatoday.com/story/news/world/2016/01/20/globalpostcolombia-acid-attacks-women-law/79065014/; http://www.bbc.com/news/world-latinamerica-35349222.

4 See, e.g., Ernie Suggs, Five Years After Savage Acid Attack Christy Sims is Rising Again, THE ATLANTA JOURNAL CONSTITUTION (Jun. 15, 2018), https:/ / www.ajc.com/news/don-feel-sorryfor-myself/WR8upjSHk8wZBoVg0A8OFP/.

${ }^{5}$ See Sujoy Dhar, Acid Attacks Against Women in India on the Rise; Survivors Fight Back, USA TODAY (Jul. 27, 2017), https://www.usatoday.com/story/news/world/2017/07/27/acid-attackswomen-india-survivors-fight-back/486007001/. 6 See Grace Yi, Acid Attacks in South Asia, The Yale Global Health Review (Oct. 15, 2015), https://yaleglobalhealthreview.com/2015/10/15/acid-attacks-in-south-asia/ ("Acid attacks occur throughout the world, but disproportionately in South Asia."); see, e.g., Human Rights Commission of Pakistan, State of Human Rights in 2017167 (Mar. 2018), http:/ / hrcpweb.org/publication/wp-content/uploads/2018/04/State-of-Human-Rights-in-2017.pdf (Eighteen incidents of acid burning were recorded in Pakistan in 2017.); see, e.g., Joanna BourkeMartignoni, Implementation of the Convention on the Elimination of All Forms of Discrimination Against Women 21 (Jun. 2001), http:/ / www.omct.org/files/2001/01/2196/vietnameng2001.pdf (In Vietnam, the Burn Unit at Cho Ray Hospital in Ho Chi Minh City treated 114 acid burn victims between 1994 and June 1997.); see, e.g., Manoj Shrestha, Acid Attacks: Men are Waging Chemical Warfare on Women and Getting Away With It, NEPALI TIMES (May 18-24, 2017), http:/ /archive.nepalitimes.com/issue/349/Nation/13549\#.XNstG9NKj-Y (In Nepal, women's rights organizations reported dozens of attacks in the eastern part of the country between 2004 and 2007.). Acid attacks have also been reported in Laos and Sri Lanka. See, e.g., Jordan Swanson, Acid Attacks: Bangladesh's Efforts to Stop the Violence, 3 INT'L HeAlth 1, 2 (2002), 
rates of acid attack violence with 225 attacks against women reported in $2016 .{ }^{7}$ Acid violence is gender-based violence and, as such, international treaty obligations require that the Indian government prevent and redress acid attacks. Non-state actors, such as corporations and businesses, also can and should play a role in preventing and addressing gender-based violence, particularly if they are involved in the supply chains that lead to human rights abuses. In 2011, the United Nations released its Guiding Principles on Business and Human Rights, which explain the role that businesses should play in preventing and remedying human rights violations. ${ }^{8}$ This Chapter claims that producers of acid and businesses that use acid in their operations also have a responsibility under these Guiding Principles to take measures to prevent acid violence and to assist victims with adequate remedy.

This Chapter draws upon and supplements a transnational field research and advocacy report (the "Acid Violence Report") on acid attacks. 9 Part I describes acid violence, its causes and consequences in the Indian context. Part II outlines India's due diligence obligations with regard to acid attack violence under the Convention on the Elimination of All Forms of Discrimination Against Women (CEDAW). Part III then examines the evolution of the business and human rights framework and makes the case for corporate accountability for acid attack violence in India. Part IV concludes, arguing that the state and corporations benefiting from the sale and use of acid have due diligence obligations to address these harms.

\section{Part I: Causes and Consequences of Acid Attack Violence in India}

Shanti ${ }^{10}$ married her husband when she was fourteen years old. Her husband abused her and continuously harassed her and her family for additional dowry. After fourteen years of her husband's abuse, she and her children moved out of their home. Her husband apologized for his behavior, promised to change, and persuaded her to return to him. When she returned, however, her husband began harassing her for dowry again. Shanti felt that her husband was "troubled" that she had been living independently of him and assumed she was unfaithful to him. On the morning of October 10, 2001, when

http:/ / www.hcs.harvard.edu/ epihc/currentissue/spring2002/swanson.php (last visited Mar. 30, 2019) (finding acid attacks reported in Laos); see, e.g., Sri Lankan Student in Coma After Acid Attack, SBS NEWS (Feb. 24, 2015), https:/ / www.sbs.com.au/news/sri-lankan-student-in-coma-afteracid-attack.

${ }^{7}$ National Crime Records Bureau, Crime in India 2016135 (Oct. 2017), http://ncrb.gov.in/StatPublications/CII/CII2016/pdfs/NEWPDFs/Crime\%20in\%20India\%20\%202016\%20Complete\%20PDF\%20291117.pdf [hereinafter Crime in India 2016 Report]. 8 United Nations Office of the High Commissioner for Human Rights, Guiding Principles on Business and Human Rights (2011), https://www.ohchr.org/documents/publications/GuidingprinciplesBusinesshr_eN.pdf.

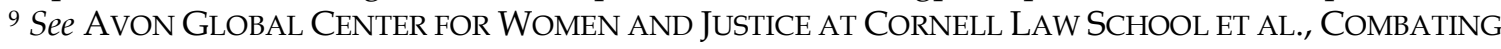
ACID VIOLENCE IN BANGLADESH, INDIA AND CAMBODIA (2010) [hereinafter AVON GLOBAL CENTER REPORT]. Stella Kwon, Gary Liao, and Kahina Selmouni conducted significant research for the report, including field-work in India, Cambodia, and Bangladesh. The authors of this article are the Report's principal authors.

10 The interviewee's name has been changed to protect confidentiality. 
Shanti brought her husband his morning cup of coffee, he threw acid at her, severely burning her face and neck.

First, Shanti was taken to a local government hospital. The hospital refused to treat Shanti because her injuries were related to a "police case" and the hospital did not want to get involved in a legal matter. She then went to another hospital where she stayed for nineteen days and received only minimal "treatment" - medical staff rubbed ointments on her burn wounds that caused further damage. Only after a private hospital admitted her did a surgeon remove the burned skin. In order to finance her treatment at the private hospital, Shanti had to sell many pieces of her jewelry. As a consequence of the attack, Shanti lost vision in one eye. Acid also dissolved one of her earlobes, seeped into her inner ears, and left her completely deaf in one ear.

The police came to speak to Shanti one week after the attack; her trial, however, began some three years later. The authorities charged her husband under Section 326 of the Indian Penal Code for "voluntarily causing grievous hurt by dangerous weapons or means." 11 When Shanti appeared in court, the judge told her to cover her face because he could not bear to look at her. The court ultimately convicted her husband and sentenced him to six years in prison and a Rs. 8,000 (\$177 USD) fine.

The attack drastically altered the socio-economic standing of Shanti's family. Shanti could no longer rent a home in a middle-class neighborhood. She applied for government subsidized housing but did not receive an answer from the government. Although she received government compensation of Rs. 2 lakhs (Rs. 200,000 or $\$ 4,522$ USD), she remains deeply in debt, and her monthly medical expenses continue to exceed Rs. 1,000 (\$22 USD). She has had trouble maintaining steady employment, and the stress and trauma of being an acid violence survivor has led to the development of a heart condition.

Shanti is one of many victims-survivors of acid attack violence in India. Acid attack violence involves intentional acts of violence in which perpetrators throw, spray, or pour acid onto the victims' faces and bodies, often intending to permanently disfigure and cause extreme physical and mental suffering to victims. ${ }^{12}$ Acid attacks cause immediate damage, disfigurement, pain and long-lasting medical complications for victims. At first contact, acid feels like water on the body, but within seconds, it causes an intense burning sensation that quickly increases to cause extreme pain. ${ }^{13}$ If not washed off and neutralized immediately with water, acid can melt away a victim's skin and flesh, going as far as dissolving bones. ${ }^{14}$

\footnotetext{
11 The Criminal Law (Amendment) Act, No. 13 of 2013, INDIA CODE (1860), available at https://www.prsindia.org/sites/default/files/bill_files/Criminal_Law_\%28A\%29\%2C_2013.pd $\mathrm{f}$.

12 See AVOn Global CENTER RePORT, supra note 9, at 1.

${ }^{13}$ See Md. Shahidul Bari \& Md. Iqbal Mahmud Choudhury, Acid Burns in Bangladesh, 14 ANNALS OF BURNS \& FIRE DISASTERS 115, 115 (2001).

${ }^{14}$ CAMbodian League FOR the Promotion of Human Rights (LICADHO), Living IN THE SHADOWS: ACID ATTACKS IN CAMBODIA 10 (2003), http:/ / www.licadho-
} 
When thrown onto the face, acid quickly burns and destroys victims' eyes, eyelids, ears, lips, noses and mouths. ${ }^{15}$ In five seconds, acid causes superficial burns, and in thirty seconds, acid produces full-thickness burns. ${ }^{16}$ Victims suffer the most physical pain from superficial wounds rather than deeper burns, as deeper wounds burn off the nerve cells. ${ }^{17}$ Burned skin dies, turns black and leathery, and severe scarring results. ${ }^{18}$ After the attacks, victims are at risk of breathing failure due to the inhalation of acid vapors, which cause either a poisonous reaction or swelling in the lungs. ${ }^{19}$ In the weeks or even months after the attack, acid burn victims who survive may suffer from infections, which can also cause death if not treated with proper cleaning techniques and antibiotics. ${ }^{20}$

Victims must endure painful surgical procedures just to prevent or mitigate further harm and suffering. ${ }^{21}$ If not washed off immediately, acid continues to burn the skin, eventually causing skeletal damage ${ }^{22}$ and organ failure. ${ }^{23}$ If dead skin is not removed from the victims' bodies within a few days, the new skin may grow and cause further facial deformities. ${ }^{24}$ If there is burned skin tissue around the neck or armpit areas, medical professionals must remove it to facilitate movement. After a while, skin may grow back and grow over victims' eyelids or nostrils, or pull on existing skin resulting in the formation of lumps. ${ }^{25}$ To avoid severe pain and further disabilities, acid burn victims - especially children whose bodies are still growing - need staged surgeries and constant physical therapy to ensure that scarred tissue remains elastic and does not harm other parts of the body. ${ }^{26}$

cambodia.org/reports/files/41acid\%20report\%20English.pdf [hereinafter LIVING IN THE SHADOWS].

15 See Law Commission of India, The Inclusion of Acid Attacks as Specific Offences in the Indian Penal Code and a Law for Compensation of Victims of Crime, Report No. 226 (Jul. 2009),

http://lawcommissionofindia.nic.in/reports/report226.pdf [hereinafter Law Commission of India Report]; Bari \& Choudhury, supra note 13, at 122.

16 See Bari \& Choudhury, supra note 13, at 120.

17 Interview with Dr. Satish, Specialist in Reconstructive Surgery, Apollo Private Hospital, in Mysore, India (Jan. 15, 2010) [hereinafter Dr. Satish Interview].

18 See Bari \& Choudhury, supra note 13, at 115; A. Faga et al., Sulphuric Acid Burned Women in Bangladesh: A Social and Medical Problem, 26 BuRNS 701, 707 (2000); see also Law Commission of India Report, supra note 15, at 10.

${ }^{19}$ Law Commission of India Report, supra note 15, at 10; LIVING IN THE SHADOWS, supra note 14, at 10.

${ }^{20}$ Law Commission of India Report, supra note 15, at 12.

${ }^{21}$ Dr. Satish Interview, supra note 17.

22 See id.

${ }^{23}$ See, e.g., Acid Attack Victim Succumbs to Burns, THE HINDU (Apr. 12, 2010), http://www.hindu.com/2010/04/12/stories/2010041262981000.htm.

${ }^{24}$ Dr. Satish Interview, supra note 17.

${ }^{25} \mathrm{Id}$.

26 See CAMBODIAN ACID SURVIVORS CHARITY (CASC), BREAKING THESILENCE: ADDRESSING ACID ATTACKS IN CAMBODIA 5, 29 (2010) [hereinafter BREAKING THESILENCE]; Interview with Ziad Samman,

Coordinator, Sophea Chhun, Program Manager, Dr. Horng Lairapo, Medical \& Legal Manager, \& 
Acid violence also leads to serious mental and emotional suffering. Survivors report higher levels of anxiety and depression, increased self-consciousness and lower levels of self-esteem as a result of their appearances, ${ }^{27}$ isolation and marginalization. Suicide is common among acid attack survivors. ${ }^{28}$

Statistics on acid attacks are not reliable. Before the Indian Penal Code (IPC) was amended in 2013 to include specific provisions on acid violence, ${ }^{29}$ the Indian government did not maintain separate data on the incidence and prevalence of acid attacks. The authors' review of Indian newspapers found 153 reported acid violence cases from January 2002 to October 2010. This number most likely underrepresents the true scope of acid violence in India during these years because not all attacks are reported in print media. The Campaign and Struggle Against Acid Attacks on Women (CSAAAW), a regional organization, found that there were 68 reported acid attacks between 1999 and 2008 in the State of Karnataka alone, suggesting that the national number is much higher than 153 for the period between January 2002 to October 2010.30 From 2010 through 2014, Acid Survivors Foundation India (ASFI) collated data from newspaper reports, indicating that acid attack incidence rates were on the rise, with 80 victims in 2010, 106 in 2011, 106 in 2012, 122 in 2013 and 130 as of November of 2014. ${ }^{31}$ Official India crime data show that, in 2016, there were 225 reported acid attacks. ${ }^{32}$

Gender discrimination motivates a significant majority of acid attacks. Perpetrators throw acid on women and girl-victims for transgressing traditional, subordinating gender roles. ${ }^{33}$ For example, Indian newspapers reported between January 2002 and October 2010 that sexual harassment - often in the form of rejected love, sex, or marriage proposals - motivated attacks in 35\% of the stories that included a motive for the attack. ${ }^{34}$ Additionally, domestic violence is widespread in India, and husbands

Pin Domnang, Unit Coordinator \& Administrative Manager, Cambodian Acid Survivors Charity (CASC), in Phnom Penh, Cambodia (Mar. 22, 2010).

${ }_{27}$ Mamta Patel, A Desire to Disfigure: Acid Attack in India, 7(2) INT'L J. OF CRIM. AND SOC. THEORY 1, 2 (Dec. 2014), http://ijcst.journals.yorku.ca/index.php/ijcst/article/viewFile/39702/35950.

28 See, e.g., Declan Walsh, Years After Acid Horror, Suicide Stirs Pakistan, N.Y. TIMES (Apr. 9, 2012), http://www.nytimes.com/2012/04/10/world/asia/hope-in-pakistan-for-curbing-acidattacks.html?pagewanted=all.

${ }^{29}$ The Criminal Law (Amendment) Act, supra note 11.

30 See Law Commission of India Report, supra note 15, at 7.

${ }^{31}$ Harsimran Gill \& Karen Dias, Indian Acid Attack Victims Share Their Stories, ALJAZEERA (Mar. 10, 2016), http:/ / www.aljazeera.com/indepth/features/2016/03/indian-acid-attack-victims-sharestories-160309074926141.html.

${ }^{32}$ Crime in India 2016 Report, supra note 7; see also Atish Patel, Reports of Acid Attacks in India are on the Rise and That's a Good Thing, THE WALL STREET JOURNAL (Mar. 21, 2015),

https:/ / blogs.wsj.com/indiarealtime/2015/03/21/reports-of-acid-attacks-in-india-are-on-therise-heres-why-thats-a-good-thing/.

33 AVON GLOBAL CENTER REPORT, supra note 9, at 2.

${ }^{34} \mathrm{Id}$. at 18; CAMPAIGN AND STRUGGLE AGAinst ACID ATTACKS ON WOMEN (CSAAAW), BURNT NOT DEFEATED 30 (2007) [hereinafter CSAAAW REPORT]. 
perpetrate a large portion of acid attacks against their wives. ${ }^{35}$ Further, a wife's parents' refusal to give more money for dowry is frequently cited as a reason for acid attacks perpetrated by the husband or the husband's family. ${ }^{36}$ Finally, newspaper stories from India indicated that, of the reports that identified motive, nearly $20 \%$ of the attacks were between unrelated people because of business disputes, sales disputes, land disputes, or revenge between families. Even these cases are gender-motivated because attacking an unmarried daughter might impose greater financial burdens on the family, as the daughter will be viewed as unmarriageable and therefore an encumbrance. ${ }^{37}$

\section{Part II: India's Due Diligence Obligations to Combat Acid Violence under the CEDAW}

Acid attack violence is a form of gender-based violence. Under the Convention on the Elimination of All Forms of Discrimination Against Women (CEDAW), states parties are obligated to prevent and adequately respond to all forms of gender discrimination, including gender-based violence. ${ }^{38}$ Specifically, the CEDAW Committee and the Special Rapporteur on Violence Against Women, Its Causes and Consequences has recognized that states must act with due diligence to prevent violations of human rights, including acts committed by private, non-state actors. ${ }^{39}$ According to the Special Rapporteur, the

\footnotetext{
35 See id. at 21, 24 (recounting Shanti's story, among others); see also Crime in India 2016 Report, supra note 7, at xix (In India, 32\% of crimes against women in 2016 were recorded in the category of "cruelty by husbands or relatives.").

36 AvOn GlObal CENTER REPORT, supra note 9, at 18.

$37 \mathrm{Id}$. at 20.

38 See Article 1, Convention on the Elimination of All Forms of Discrimination Against Women [CEDAW], Dec. 18, 1979, 1249 U.N.T.S. 13, 19 I.L.M. 33 (1980); CEDAW Committee, General Recommendation No. 19: Violence Against Women (1992), https://tbinternet.ohchr.org/Treaties/CEDAW/Shared\%20Documents/1_Global/INT_CEDAW _GEC_3731_E.pdf, at 6 (the Committee on the Elimination of all forms of Discrimination Against Women (CEDAW Committee), which monitors State compliance with the treaty, describes gender-based violence as "violence that is directed against a woman because she is a woman or that affects women disproportionately.") [hereinafter General Recommendation No. 19]. We note that, although CEDAW recognizes gender-based violence as something that occurs only to women, it is recognized that men can also be subject to violence because of their gender. See, e.g., Judy A. Benjamin \& Khadija Fancy, The Gender Dimensions of Internal Displacement 14 (Nov. 1998), https://reliefweb.int/sites/reliefweb.int/files/resources/0D530FFE231BCDB6C1256C360045B8 B4-Gender\%20Dimension.pdf; United Nations International Research and Training Institute for the Advancement of Women (INSTRAW), Partners in Change: Working with Men to End GenderBased Violence (2002), http:/ / menstoppingviolence.org/cms/docs/PartnersInChangepp1-37.pdf; Human Rights Watch, The War Within the War: Sexual Violence Against Women and Girls in Eastern Congo (Jun. 2002), https:/ / www.hrw.org/reports/2002/drc/Congo0602.pdf; Jeanne Ward, If Not Now, When? (2002) https://www.womensrefugeecommission.org/tags/srh/document/download/241; R. Charli Carpenter, Recognizing Gender-Based Violence Against Civilian Men and Boys in Conflict Situations, 37 SECURITY DiALOGUE 83 (2006).

39 The Special Rapporteur on Violence Against Women, its Causes and Consequences, Yakin Ertürk, Report on The Due Diligence Standard as a Tool for the Elimination of Violence Against Women, I 20, delivered to the Economic and Social Council Commission on Human Rights, U.N. Doc.
} 
State's due diligence obligation includes the duty to prevent, protect, investigate, prosecute, punish, and provide redress to victims. ${ }^{40}$ Below we discuss India's duties as State party to the CEDAW to combat acid violence as a form of gender-based violence.

\section{Acid Violence is Gender-Based Violence}

Gender-based violence is any form of violence that either disproportionately affects women or results from gender discrimination and inequality. The CEDAW Committee has noted that gender-based violence both results from and perpetuates traditional discriminatory attitudes that confine women and girls to stereotypical, subordinate roles and positions. ${ }^{41}$ Acid violence both disproportionately affects women and girls and results from gender discrimination and inequality. From our analysis of media reports, we found that $72 \%$ of reported cases of acid attacks are perpetrated against women. ${ }^{42}$

In addition, acid violence results from gender discrimination and inequality. Although acid violence occurs in many countries, it is particularly prevalent in contexts in which there is significant gender discrimination. India ranks very low on the Global Gender Gap Index, which measures national economic, educational, health and political equality between men and women..$^{43}$ In 2018, India ranked 108th out of 149 countries included in the Global Gender Gap Index. ${ }^{44}$ A strong societal preference for sons is another indicator of the undervaluation of women relative to men. In India, the child sex ratio, defined as number of girls for every 1000 boys age 0 to 6, has decreased from 927 in 2001 to 919 in 2011,45 which indicates that son preference has become even more prevalent in the country in recent years. In 2017, one study found that among Indian women aged 15 to 49 , only $4 \%$ want to have more daughters than sons, whereas $19 \%$ want to have more sons than daughters. ${ }^{46}$

Perpetrators often intend to destroy what society considers one of the most valuable traits of a woman - her beauty. One author who interviewed rejected suitors who perpetrated acid attacks in Bangladesh noted that perpetrators mean to "punish"

E/CN.4/2006/61 (Jan. 20, 2006) [hereinafter Special Rapporteur on Violence Against Women, Yakin Erturk]; See General Recommendation No. 19, supra note 38, at 99.

${ }^{40}$ Special Rapporteur on Violence Against Women, Yakin Erturk, supra note 39, at 935.

${ }^{41}$ See General Recommendation No. 19, supra note 38, at 11 (remarking that "[t]raditional attitudes by which women are regarded as subordinate to men or as having stereotyped roles perpetuate widespread practices involving violence or coercion, such as family violence and abuse, forced marriage, dowry deaths, acid attacks and female circumcision.") [emphasis added].

${ }^{42}$ AvON GLOBAL CENTER RePORT, supra note 9, at 13.

43 See World Econ. Forum, The Global Gender Gap Report 2018 (2018),

http://www3.weforum.org/docs/WEF_GGGR_2018.pdf [hereinafter The Global Gender Gap Report].

${ }^{44}$ Id.; see also Francis Kuriakose, Neha Mallick \& Deepa Kylasam Iyer, Acid Violence in South Asia: A Structural Analysis toward Transformative Justice, 2(1) SAGE PUBLICATIONS (2017) (arguing for the need for a structural approach to acid attacks that considers socio-economic issues, including neo-liberal reform policies).

${ }^{45}$ Government of India, A-5 Union Primary Census Abstract - 2011, http://www.censusindia.gov.in/2011census/hlo/pca/PCA_Data_India.html.

${ }^{46}$ International Institute for Population Sciences (IIPS), National Family Health Survey (NFHS-4)

(Dec. 2017), https://dhsprogram.com/pubs/pdf/FR339/FR339.pdf. 
women for being "proud" of their attractive features. ${ }^{47}$ In addition, some perpetrators also intend to burden an entire family by attacking the female family member given that society will consider the victim unmarriageable and must thereafter be supported by her family.

Acid violence not only reflects gender discrimination and inequality but also perpetuates it. Society shuns survivors whose faces have been severely burned. Some survivors cover their faces when going outside of their houses to avoid stares and comments from onlookers. Many people consider victims' scarred faces to be bad omens. ${ }^{48}$ In societies where many "girls grow up to get married," a girl's value is often measured in terms of her ability to marry and marry well. ${ }^{49}$ Thus, destroying a young girl's marriage prospects by disfiguring her can amount to ending her life by making her worthless in society's eyes. ${ }^{50}$

Acid violence victims are often perceived to have committed an immoral act, such as having an extramarital affair. ${ }^{51}$ As a result of this alleged or real social transgression, others in their communities may view them as outcasts and even believe that they deserved their fates. ${ }^{52}$ One expert noted that "[a]fter an attack, if you talk to neighbors, they will say, 'Why was this particular woman [attacked]? There must have been problems with her.'" 53 Thus, acid violence victims almost always face social stigma after the attack. ${ }^{54}$

Acid attacks are interpersonal acts of violence and are rarely specifically motivated by a desire to promote fear among other women. Nonetheless, individual incidents of acid attacks may make women fearful of transgressing social norms that keep them in subordinated positions. Acid violence has the effect of signaling, not only to victims, but also to all women in a society in which such violence widely occurs, that they must not counter prevailing gender norms.

Consequently, acid violence is gender-based violence as defined by the CEDAW because acid attacks both disproportionately affect women and perpetuate gender inequality. By viewing acid violence as gender-based violence obligates India, which has ratified the

\footnotetext{
${ }^{47}$ Interview with Md. Mahbubul Haque, Trustee \& Director, Policy Research Center, in Dhaka, Bangladesh (Dec. 10, 2009) [hereinafter Md. Mahbubul Haque Interview].

${ }^{48}$ Interview with Rehana Rahman, Samina Afrin, Jahanara Ansar, Masreen Awal Mintoo \& Cynthia Farid, Program Officer, ABA Rule of Law Initiative, in Dhaka, Bangladesh (Dec. 10, 2009) (statement by Cynthia Farid).

${ }^{49} \mathrm{Id}$. ("A lot of the women here, they grow up with the desire to get married.").

$50 \mathrm{Id}$.

51 See NGO Roundtable Discussion hosted by the Cambodian League for the Promotion \& Defense of Human Rights (LICADHO), in Phnom Penh, Cambodia (Mar. 23, 2010); interview with Usha, Campaign and Struggle Against Acid Attacks on Women (CSAAAW), in Bangalore, India (Jan. 19, 2010) [hereinafter Usha Interview]; Md. Mahbubul Haque Interview, supra note 47.

52 See Md. Mahbubul Haque Interview, supra note 47; Breaking the Silence, supra note 26, at 34.

${ }^{53} \mathrm{Md}$. Mahbubul Haque Interview, supra note 47.

${ }^{54}$ Interview with Anonymous, NGO, in Phnom Penh, Cambodia (Mar. 23, 2010) ("Many people are prejudiced against the mistress; many believe she deserves the attack.").
} 
CEDAW, to combat all forms of discrimination against women, including acid violence.

India's Due Diligence Obligations to Prevent and Adequately Respond to Acid Violence Given that acid violence is gender-based violence, India is obligated to combat it, including through: preventing acid attacks by, among other things, enacting and enforcing laws to specifically address acid violence, its causes and consequences; investigating attacks; protecting victims and witnesses to attacks; prosecuting and punishing perpetrators; and remedying victims' harms. India has made some progress in fulfilling its obligations under the CEDAW with regard to acid violence, outlined below, with suggestions for further reform.

\section{Enacting Effective Laws to Combat Acid Violence}

The duty to prevent human rights violations includes an obligation to enact legislation designed to ensure that women are free from gender-based violence. 55 Both the Law Commission of India ${ }^{56}$ and the National Commission for Women (NCW) ${ }^{57}$ long supported enacting amendments to the IPC and Indian Evidence Code to address acid attack violence. While the government stated in a public interest litigation court filing in April 2010 before the Supreme Court of India that the "existing legislations are sufficient to deal with the offense of acid attack," 58 authorities later reversed this position, at least with respect to adopting criminal provisions. Before enacting specific provisions on acid attacks, some judges applied criminal code provisions that required less serious criminal penalties when compared to the magnitude of harm. ${ }^{59}$

It was the horrific gang rape and death of 23-year-old student Jyoti Singh Pandey on a bus in Delhi in December $2012^{60}$ that galvanized the Indian Parliament to adopt specific measures against acid violence. The incident made international headlines and generated national protests. As a result, the government convened the Justice Verma

\footnotetext{
${ }^{55}$ See General Recommendation No. 19, supra note 38, at 9 9, 24. In A.T. v. Hungary, the CEDAW Committee found that Hungary violated its obligations under the CEDAW by failing to enact legislation designed to combat domestic violence and sexual harassment, and to provide "protection or exclusion orders or shelters exist[ing] for the immediate protection" of victims of domestic violence. CEDAW Committee, Comm. 2/2003, A.T. v. Hungary, ๆ 9.3, A/60/38 (Part I) (Jan. 26, 2005).

${ }^{56}$ Law Commission of India Report, supra note 15, at 43.

57 Both the Law Commission of India and the National Commission for Women recommended adding a section 326A to the Indian Penal Code and a section 114B to the Indian Evidence Code. Id. at 43-44; NATIONAL COMMISSION FOR WOMEN, PREVENTION OF OFFENCES (BY ACIDS) ACT 2008 DRAFT BILl 15-16 (2008) (cited in AVON GLOBAL CENTER RePORT, supra note 9, at 33).

${ }^{58}$ Dhananjay Mahapatra, No Change in Law Needed to Make Acid Attack a Heinous Offence: Centre, TIMES OF INDIA NEW DELHI EDITION, Apr. 15, 2010, at 10, available at http:/ / timesofindia.indiatimes.com/india/No-change-in-law-needed-to-make- acid-attack-aheinous-offence-Centre/articleshow/5804710.cms (last visited May 16, 2019). ${ }_{59}$ Ajita Tandon, Analysis of the Judicial and Legislative Approach on Acid Attack Victims in India, 1 NCRB Journal 44, 45-46 (2018), available at http://ncrb.gov.in/NCRB_Journal/NCRB_Journal_October_2018.pdf [hereinafter Tandon]. 60 See Niharika Mandhana \& Anjana Trivedi, Indians Outraged Over Rape on Moving Bus in New Delhi, N.Y. TIMES (Dec. 18, 2012), https:/ /india.blogs.nytimes.com/2012/12/18/outrage-in-delhiafter-latest-gang-rape-case.
} 
Committee to propose a series of amendments to improve the criminal justice response to gender-based violence crimes. ${ }^{61}$ On January 23, 2013, the Committee recommended that Parliament pass proposed amendments to the IPC explicitly to criminalize acid attacks, to increase punishment for perpetrators, to ensure that perpetrators pay fines to victims, and to establish a state victim compensation scheme for such crimes. ${ }^{62}$

Shortly thereafter, in response to international and national pressure, the Indian Parliament passed amendments to laws strengthening the state response to genderbased violence, including acid attacks. Specifically, the Indian legislature amended the IPC to include Articles 326A and 326B, criminalizing nationally acid attacks and attempted acid attacks. ${ }^{63}$ As a result, the government now considers acid attacks and other similar attacks to be specific crimes causing "grievous hurt." 64 The law mandates that perpetrators receive a minimum of ten years and a possibility of life sentences in prison and pay fines directly to victims to cover their medical expenses. ${ }^{65}$ Perpetrators who attempt an acid attack can receive five to seven years in prison and fines. ${ }^{66}$

The amendments also modified the Criminal Procedure Code (CPC). Section 357B ensures that victims of acid attacks receive state compensation in addition to perpetrator fines. ${ }^{67}$ Section $357 \mathrm{C}$ mandates that all public and private hospitals provide free first aid and medical treatment to acid violence victims and report incidents immediately to

${ }^{61}$ Committee on Amendments to Criminal Law, Report of the Committee on Amendments to Criminal Law 146-48 (Jan. 2013), https://www.prsindia.org/uploads/media/Justice\%20verma\%20committee/js\%20verma\%20co mmitte\%20report.pdf [hereinafter Justice Verma Committee Report].

62 Id.

${ }^{63}$ Amendments: Articles 326A \& B of the IPC. The new provisions read as follows: 326A. Whoever causes permanent or partial damage or deformity to, or burns or maims or disfigures or disables, any part or parts of the body of a person or causes grievous hurt by throwing acid on or by administering acid to that person, or by using any other means with the intention of causing or with the knowledge that he is likely to cause such injury or hurt, shall be punished with imprisonment of either description for a term which shall not be less than ten years but which may extend to imprisonment for life, and with fine:

Provided that such fine shall be just and reasonable to meet the medical expenses of the treatment of the victim:

Provided further that any fine imposed under this section shall be paid to the victim."

326B. Whoever throws or attempts to throw acid on any person or attempts to administer acid to any person, or attempts to use any other means, with the intention of causing permanent or partial damage or deformity or burns or maiming or disfigurement or disability or grievous hurt to that person, shall be punished with imprisonment of either description for a term which shall not be less than five years but which may extend to seven years, and shall also be liable to fine.

64 The Criminal Law (Amendment) Act, supra note 11.

$65 \mathrm{Id}$.

66 Id.

67 See id. ("The compensation payable by the State Government under section 357A shall be in addition to the payment of fine to the victim under section 326A or section 376D of the Indian Penal Code.") 
police. ${ }^{68}$ Moreover, amendments to Section 100 of the CPC include a specific right of selfdefense, including causing the perpetrator's death, in the case of an acid attack or attempted acid attack. ${ }^{69}$

Parliament has not enacted legislation specifically addressing acid supply chains or corporate accountability for acid attacks. ${ }^{70}$ One of the reasons acid violence occurs is the cheap and easy availability of acid. On July 16, 2013, after a string of acid attacks, ${ }^{71}$ the Indian Supreme Court ruled in WP(Crl.)129 of 2006 Laxmi v. Union of India $\mathcal{E}$ Ors. ${ }^{72}$ that the Federal and state governments must regulate the sale of acid used to perpetrate acid violence. ${ }^{73}$

Specifically, the order mandates that:

- States and union territories issue licenses to retailers who sell acid;

- Retailers do not sell acid over the counter unless they keep record of the quantities sold and the details, including addresses, of buyers;

- States and retailers prohibit sales of hydrochloric, nitric, and sulfuric acid to anyone under 18 years old;

- Buyers present photo identification and declare purpose for purchasing acid;

- Retailers declare the amount of acid they have stocked to the Police; and

${ }^{68} I d$. ("All hospitals, public or private, whether run by the Central Government, the State Government, local bodies or any other person, shall immediately, provide the first-aid or medical treatment, free of cost, to the victims of any offence covered under section 326A, 376, 376 A, 376B, 376C, 376D or section 376E of the Indian Penal Code and shall immediately inform the police of such incident.")

${ }^{69} I d$. ("Section 100: The right of private defence [sic] of the body extends, under the restrictions mentioned in the last preceding section, to the voluntary causing of death or of any other harm to the assailant, if the offence which occasions the exercise of the right be of any of the descriptions hereinafter enumerated, namely: 'Seventhly- An act of throwing or administering acid or an attempt to throw or administer acid which may reasonably cause the apprehension that grievous hurt will otherwise be the consequence of such act.'")

${ }^{70} I d$. ("In addition, there has been several directions issued by the Hon'ble Supreme Court of India regarding compensation, free medical treatment and regulating sale of acids, all of which have been welcomed by us.")

71 See India Gender Violence: Four Sisters Severely Burnt in Acid Attack, INT'L Bus. TIMES (Jul. 2014), http://www.ibtimes.co.uk/acid-attack-india-uttar-pradesh-sisters-gangrape-453001; Neeta Lal, Acid Attacks Still a Burning Issue in India (Apr. 2015), http:/ / www.ipsnews.net/2015/04/acidattacks-still-a-burning-issue-in-india/.

72 See Mohit Singh, Laxmi v. Union of India - (2014) 4 SCC 427 - (Acid Attack Compensation Order), 1, LAW STREET (Dec. 8, 2015), http:/ / onelawstreet.com/2013/07/laxmi-vs-union-of-india-2014-4scc-427-acid-attack-compensation-order/.

73 See India Supreme Court Orders Curb on Sales of Acid, BBC NEWs (Jul. 18, 2013), http://www.bbc.com/news/world-asia-india-23358264; KumKum Dasgupta, India's Acid Attack Survivors Welcome Rules to Help Stop Rise in Assaults, THE GUARDIAN (Jul. 18, 2013), https:// www.theguardian.com/global-development/2013/jul/18/india-acid-attack-survivorscompensation; India's Top Court Moves to Curb Acid Attacks, ALJAZEERA (Jul. 18, 2013), https://www.aljazeera.com/news/asia/2013/07/2013718134222947132.html. 
- Police confiscate any undeclared stock and fine retailers up to 50,000 rupees. ${ }^{74}$

Years after this order, acid continues to be easily available in India. The Indian government has not passed a specific statute prohibiting acid sales, 75 and police rarely enforce the existing Supreme Court guidelines and laws. ${ }^{76}$

Following Bangladesh's example, India should adopt a law regulating acid sales. In 2002, Bangladesh adopted the Acid Crime Control Act (ACCA) and the Acid Control Act (ACA). The ACCA heightened criminal penalties and tightened criminal procedures for acid violence cases, and the ACA created a licensing regime that regulates the sale, storage, distribution, and use of acid.

Since Bangladesh passed laws regulating the sale of acid in 2002, reported acid attacks have been steadily decreasing by $15 \%$ to $20 \%$ each year. ${ }^{77}$ Although Bangladesh's two acid violence laws were adopted in 2002, heightened penalties for perpetrating acid attacks had been in effect since 1984. In that year, Bangladesh adopted a new section of its penal code (Section 326A), allowing judges to impose the death penalty if the victim had been blinded or her head or face was permanently disfigured. ${ }^{78}$ However, despite the adoption of the death penalty for acid violence in 1984, the number of acid attacks reported in Bangladesh continued to increase until 2002.79

Enacting the Acid Control Act in 2002 marked the first time that Bangladesh took steps to regulate and monitor the use, sale, purchase, storage, transportation, import, and export of acid, and to punish unauthorized sales. ${ }^{80}$ The significant decrease in acid attacks after 2002 is associated with the introduction of acid regulations, changes to the criminal justice system, and increased public awareness of criminal punishment and

\footnotetext{
${ }^{74}$ See India Supreme Court Orders Curb on Sales of Acid, supra note 73; see also, \#India - SC Order Regarding Acid Attacks \#Vaw \#Womenrights, KRACTIVIST.ORG, https:/ / kractivist.org/india-scorder-regarding-acid-attack-vaw-womenrights/.

${ }^{75}$ But see The Poisons Act, No. 12 of 1919, INDIA CODE (1860), available at https://indiacode.nic.in/bitstream/123456789/5751/1/the_poisons_act\%2C_1919.pdf (regulating poisonous substances without specifically enumerating acid). See Tandon, supra note 59 , at 46.

${ }^{76}$ Snigdha Poonam, Four Years After the Ban, Acid Sales in Free Flow Under Supreme Court's Nose, HINDUSTAN TIMES (Apr. 4, 2017), https:/ / www.hindustantimes.com/india-news/four-yearsafter-ban-acid-sales-in-free-flow-under-supreme-court-nose/story00tu9xW1AEFGwMChlrp7ML.html; Shweta Sengar, Despite SC Ban Stating Acid Attacks 'Heartless' Crime, Acid Sales in Free Flow Across Country, INDiA TiMES (Mar. 19, 2019), https://www.indiatimes.com/news/india/despite-sc-ban-stating-acid-attacks-heartless-crimeacid-sales-in-free-flow-across-country-363940.html. 77 ACID SURVIVORS FOUNDATION (ASF), ANNUAL REPORT 2015, http://www.acidsurvivors.org/images/frontImages/Annual_Report_-_2015.pdf, at 8. (In 2010, there were 122 incidents, then 91 (2011), 71 (2012), 70 (2013), 59 (2014), 59 (2015), 44 (2016), 39 (2017) and 18 (2018)) [hereinafter ASF ANNUAL REPORT 2015].

78 Bangl. Pen. Code, No. XLV of $1860 \S 326$ A.

79 ASF ANNUAL REPORT 2015, supra note 77.

80 Bangl. Acid Control Act (ACA), Ch. 4, No. 1 of 2002.
} 
consequences for acid attack victims. ${ }^{81}$ This decrease in attacks occurred despite problems with enforcement of the acid regulations. ${ }^{82}$ Thus, the Indian government should consider strengthening its acid sale and control laws as a way to counter acid attacks.

\section{Ensuring Implementation of Laws}

India must not only enact targeted legislation and policies to address acid violence, but it must also implement such laws. In a case against Austria, the CEDAW Committee concluded that due diligence obligations require that states implement laws to combat gender-based violence. ${ }^{83}$ Although India increased penalties for acid attacks in 2013, implementation and enforcement of the IPC is critical for compliance with due diligence obligations. In order to effectively implement laws designed to combat acid violence, India must: (1) conduct appropriate investigations, (2) protect victims from threats that could undermine those investigations, and (3) prosecute and punish perpetrators of acid attacks. The Union and state governments must make greater efforts to implement existing laws against acid violence, including the Indian Supreme Court order in Laxmi v. Union of India $\mathcal{E}$ Ors. ${ }^{84}$

\section{Duty to Investigate}

India's due diligence obligation to protect individuals from violence encompasses the duty to conduct serious, impartial, prompt, and effective investigations. ${ }^{55}$ According to the Inter-American Court of Human Rights, deficiencies in investigations "often prevent and/or obstruct further efforts to identify, prosecute and punish those responsible." 86 Though not binding on India, it is useful to note that the Inter-American Court of

\footnotetext{
${ }^{81}$ ASF ANNUAL RePORT 2015, supra note 77; e-mail from Dr. Saira Rahman Khan, Assistant Professor of Law, BRAC University, and member, ODHIKAR, to Jocelyn Getgen Kestenbaum (Dec. 20, 2010, 12:03:09 AM EST).

82 Bangl. Acid Control Act (ACA), Ch. 4, No. 1 of 2002.

${ }^{83}$ In Yildrim v. Austria and Goekce v. Austria, the CEDAW Committee concluded that, although Austria had established a comprehensive framework to address domestic violence, the State failed to satisfy its due diligence obligation of protection with respect to these two victims. The abused victims' murders directly resulted from the state authorities' failure to respond in a timely and appropriate fashion to a situation they knew or should have known to be extremely dangerous. See CEDAW Committee, Comm. 6/2005, Yildrim v. Austria, CEDAW/C/39/D/6/2005, ๆ 12.1.4 (Aug. 6, 2007); CEDAW Committee, Comm. 5/2005, Goekce v. Austria, CEDAW/C/39/D/5/2005, ๆ 12.1.6 (Aug. 6, 2007).

${ }^{84}$ Indian Supreme Court, WP(Crl.)129 of 2006 Laxmi v. Union of India \& Ors.

85 See, e.g., Velasquez Rodriguez v. Honduras, Inter-Am. Ct. H. R. (Ser. C) No. 4, at 177 (Jul. 29, 1998); González et. al. ("Campo Algodonero") v. The United States of Mexico, Inter-Am. Ct. H. R., (Ser. C) No. 205, at 9289 (Nov. 16, 2009); Opuz v. Turkey, App. 33401/02, ๆ 161 (Eur. Ct. H. R., June 9, 2009); Basic Principles and Guidelines on the Right to a Remedy and Reparation for Victims of Gross Violations of International Human Rights Law and Serious Violations of International Humanitarian Law, G.A. Res. 60/147, Part. II.3.b, U.N. GAOR, 60th Sess., 64th plen. mtg., U.N. Doc. A/RES/60/147 (Dec. 16, 2005) [hereinafter Basic Principles and Guidelines on the Right to a Remedy and Reparation].

86 Inter-American Court of Human Rights, The Situation of the Rights of Women in Ciudad Juárez, Mexico: The Right to Be Free from Violence and Discrimination, OEA/Ser.L/V/II.117, Doc. 44, March 7,2003, ๆ 137.
} 
Human Rights recently affirmed that the State has a heightened duty of care in investigating matters concerning violence against women. ${ }^{87}$ India's commitment to serious and effective investigations reiterates the condemnation of violence against women by society and ensures women's trust in the authorities' ability and dedication to protect them from violence. ${ }^{88}$

Acid victims note that they are reluctant to report acid attacks to the police because they fear harassment and ridicule from police officers. ${ }^{89}$ Some police officers espouse blatantly sexist views. For instance, an advocate recounted that one police officer, when asked why he felt that certain women are attacked with acid, answered: "These women dress up like boys. What do they expect?"90 Additionally, officers may frame acid violence investigations in terms of a woman's sexual history and questions of morality. ${ }^{91}$ For example, an investigating officer blamed one victim for the acid attack against her, saying that she instigated the crime by engaging in a series of "affairs" with co-workers, which led to one of the co-workers throwing acid at her. ${ }^{92}$ The Delhi Deputy Commissioner of Police, who believes that acid violence is a form of gender-based violence, agrees on the need to more broadly "sensitize the police force" to the specific issues faced by acid attack victims. ${ }^{93}$ Recommendations also have included ensuring that the National Commission of Women or similar bodies take proactive measures to encourage reporting and taking reported threats seriously. ${ }^{94}$

Additionally, some police officers are susceptible to corruption. Indeed, several acid attack victims reported that their attackers bribed the police with money in order to influence investigations. For example, Jacquiline Asha claims her attacker gave the police a bribe; thereafter she faced threats from the officers to withdraw the case. ${ }^{95}$ Thus, there are some reported deficiencies in police investigations of acid attacks.

\section{Duty to Protect Victims}

India's due diligence obligation includes the obligation to protect the victim from threats and harm by the perpetrator. ${ }^{96}$ This duty has been recognized as owed to the victim, but could also be extended to include the victim's family or witnesses in a criminal case against the perpetrator.

There are several documented cases in which acid attack victims have received

\footnotetext{
87 See González et al. ("Campo Algodonero”) v. The United States of Mexico, at \ 293.

88 See id. (analogizing its approach to violence against women with the European Court of Human Rights' approach to racial violence).

89 See CSAAAW REPORT, supra note 34, at 46.

90 Usha Interview, supra note 51.

91 See CSAAAW REPORT, supra note 34, at 47.

92 See id. at 48.

93 E-mail message from Sagar Preet Hooda, Deputy Commissioner of Police, Delhi Police, May 2010, in response to a query posted by the KRITI Team on the Resource Team and Members, Solution Exchange for Gender Community - an initiative of UN agencies in India.

94 See Tandon, supra note 59, at 57.

95 See CSAAAW REPORT, supra note 34, at 50.

96 Special Rapporteur on Violence Against Women, Yakin Erturk, supra note 39, at 92.
} 
inadequate police protection even when they have complained of harassment by their perpetrators prior to the attack. For instance, acid violence victim Shri Mahaveer Singh filed a police complaint stating that a man was harassing her and threatening to kill her, abduct her, and throw acid on her if she did not marry him. ${ }^{97}$ Her father requested that police protect his daughter from harm and included the name and description of the man harassing Shri in his complaint. 98 The police failed to take any action to protect her, and two years later the harasser threw acid at Shri. ${ }^{99}$ A subsequent National Human Rights Commission investigation found the police to be negligent in failing to protect Shri and deemed their negligence the proximate cause of the acid burn injuries Shri suffered. ${ }^{100}$ In Dr. Mahalakshmi's case, the police ridiculed her unmarried status when she filed complaints of harassment against the man who later attacked her with acid.101

\section{Duty to Prosecute and Punish Perpetrators}

The duty to prosecute and punish perpetrators of violence is an essential part of India's obligation to act with due diligence to protect women from violence. ${ }^{102}$ The duty to adequately prosecute and punish may include creating specialized investigatory or prosecutorial units, 103 implementing witness and victim protection programs designed, in part, to safeguard the availability of essential testimonial evidence, ${ }^{104}$ and ensuring that law enforcement procedures and personnel adapt to the specific issues and problems related to gender-based violence. ${ }^{105}$

Reports indicate that perpetrators of acid attacks are not effectively prosecuted. Given their extensive caseloads and lack of training, public prosecutors do not have the time or resources to properly investigate and prosecute cases. ${ }^{106}$ For instance, Gita was unconscious for several days after the attack against her and could not give a statement to the police. ${ }^{107}$ Since then she has attempted several times to meet with the public prosecutor, but he has refused to meet with her. ${ }^{108}$ One High Court Chief Justice urged more cooperation between victims and prosecutors and allowing victims an opportunity to play a more active role in prosecutions. ${ }^{109}$

\footnotetext{
${ }^{97}$ National Human Rights Commission (NHRC), Action Details, File Number 719/30/98-99, 14 September 1998 [hereinafter NHRC Action Details File Number 719/30/98-99].

98 Id.

$99 \mathrm{Id}$.

$100 \mathrm{Id}$.

101 See CSAAAW REPORT, supra note 34, at 46.

102 Special Rapporteur on Violence Against Women, Yakin Erturk, supra note 39, ๆ 50.

$103 \mathrm{Id}$.

$104 \mathrm{Id}$.

$105 \mathrm{Id}$.

106 See Interview with Sheela Ramanathan, Campaign and Struggle Against Acid Attacks on Women (CSAAAW) \& Human Rights Law Network (HRLN) of Bangalore, in Mysore, India (Jan. 18, 2010).

107 Usha Interview, supra note 51.

$108 \mathrm{Id}$.

109 Telephone interview with Justice Bannurathum, Chief Justice of Kerala High Court (Jan. 19, 2010).
} 
The role of judges is crucial to ensuring that acid attack perpetrators are adequately punished. Gender insensitivity and other structural problems within the Indian judiciary present challenges for the punishment of acid attack perpetrators. In one case, for example, the judge hearing an acid attack case asked the survivor to cover her face when she appeared in court. 110 In cases in which judges have imposed stiff punishments on acid attackers, it appears that, in assessing the harm to the victim, judges have given great weight to the fact that the victim has lost her chance to be married and to be a mother. ${ }^{111}$ Thus, if a judge believes that the perpetrator has prevented a woman from satisfying her traditional role as mother or wife, then the perpetrator is likely to receive a higher sentence.

\section{Providing Redress to Victims}

India's due diligence obligation includes the duty to provide redress to victims for the violations suffered. Appropriate remedies can take the forms of restitution, compensation, rehabilitation, satisfaction, and guarantees of non-repetition. ${ }^{112}$ Compensation covers awarding monetary damages proportional to the gravity of the violation. ${ }^{113}$ Rehabilitation includes medical and psychological care as well as legal and social services. ${ }^{114}$

Remedies for acid attack victims are essential and should include providing adequate healthcare in government facilities, and, where public healthcare is not available, the government should pay the expenses for treatment at private health facilities. ${ }^{115}$ Additionally, healthcare professionals who first respond to acid attack victims must be trained in the proper first aid response. Moreover, the multiple and complex surgeries survivors require are very costly, and governments should provide the specialized expertise, facilities, and resources for necessary procedures. Finally, although emphasis should be on assisting victims' transition back to work and to society, 116 acid attack survivors should receive compensation if they are unable to work for health reasons or because of the discriminatory attitudes of potential employers. ${ }^{117}$

110 See CSAAAW REPORT, supra note 34, at 22-23.

111 See id. at 58.

112 See Basic Principles and Guidelines on the Right to a Remedy and Reparation, supra note 85, at T 18. For a discussion of the right to reparation for women subjected to violence, see The Special Rapporteur on Violence Against Women, Its Causes and Consequences, Rashida Manjoo, Promotion and Protection of all Human Rights, Civil, Political, Economic, Social and Cultural Rights, Including the Right to Development, delivered to the Human Rights Council, U.N. Doc. No. A/HRC/14/22 (Apr. 23, 2010), available at http://www2.ohchr.org/english/bodies/hrcouncil/docs/14session/A.HRC.14.22.pdf. 113 See Basic Principles and Guidelines on the Right to a Remedy and Reparation, supra note 85, at ๑ 20.

114 Id. at 921.

115 In addition to providing healthcare as a form of reparations, States have independent obligations under human rights law to guarantee the right to health. See, e.g., International Covenant on Economic, Social and Cultural Rights (ICESCR), G.A. Res. 2200A (XXI), art. 11, U.N. Doc. A/6316 (Dec. 16, 1966).

116 See Tandon, supra note 59, at 57.

117 See, e.g., CSAAAW REPORT, supra note 34 (discussing how Kan Chetchea, an acid attack survivor, and his family have no source of income and rely on other family members to provide 
Even though the Indian Supreme Court has ordered Indian states to set up Victim Compensation Schemes to compensate a minimum of 300,000 rupees ( $\$ 4800$ USD) and ensure free medical care to acid attack victims, we do not know if states have complied with the order. ${ }^{118}$ The time lag to resolve cases in the Indian court system can further harm victims. In many cases, acid attack survivors do not receive compensation until after the case reaches final resolution. ${ }^{119}$

Moreover, surgeries for victims often cost much more than the compensation amount. Even private hospitals must provide free medical care according to the Indian Supreme Court, including specialized surgeries, medicines and food.120 The Indian Supreme Court has mandated that the District Legal Services Authority of each state ensure adequate compensation for claims and take action against private hospitals that refuse to treat acid attack victims. ${ }^{121}$

Even with Court-mandated treatment, unacceptable quality of treatment continues and can be attributed in part to the lack of facilities for proper care. Most government hospitals in India, like those in the other countries studied, do not have plastic surgeons or medical facilities necessary to conduct essential procedures for acid survivors. ${ }^{122}$ For instance, in Bangalore, India, the Burn Center at the primary public hospital has about 60 beds for a region with a population of over 12 million people. ${ }^{123}$ In addition, there is a shortage of plastic surgeons in the country. According to one medical expert, there are only around 2,500 plastic surgeons in a country of one billion people. ${ }^{124}$ Even if there were more trained healthcare professionals, hospitals do not have the facilities and equipment to support them. ${ }^{125}$

The government has taken a positive step to compensate victims in the Right of Persons with Disabilities Act, 2016. ${ }^{126}$ The Act's provisions include acid attack victims under the list of persons with disabilities, giving acid survivors preference for employment,

food); Tanbira Talukder, Acid Throwing-A Serious Human Rights Violation in Bangladesh, MUKTOMONA (discussing the limited employment opportunities for acid attack survivors), http://www.mukto-mona.com/Articles/talukder/acid_throwings_BD.htm; see Law Commission of India Report, supra note 15, at 4.

118 Laxmi v. Union of India, (2014) 4 SCC 427.

119 See Tandon, supra note 59, at 57.

120 Amit Anand Choudhary, Treat Acid Attack Victims for Free, Supreme Court Orders Private Hospitals, THE TIMES OF INDIA (Apr. 10, 2015), http://timesofindia.indiatimes.com/india/Treatacid-attack-victims-for-free-Supreme-Court-orders-private-hospitals/articleshow/46884560.cms. ${ }^{121}$ Laxmi v. Union of India, supra note 118.

122 Dr. Satish Interview, supra note 17.

${ }^{123}$ Smitha Sriram Segu, Our Burns Ward, 23:9-11 InDIAN J. BuRNS (2015), http:/ / www.ijburns.com/article.asp?issn=0971653X; year=2015; volume $=23$; issue $=1$; spage $=9$; epage $=11$; aulast $=$ Segu .

124 See Dr. Satish Interview, supra note 17.

${ }^{125} \mathrm{Id}$.

126 The Right of Persons with Disabilities Act, No. 49 of 2016, INDIA CODE (1860), available at http://www.disabilityaffairs.gov.in/upload/uploadfiles/files/RPWD\%20ACT\%202016.pdf. 
education and other opportunities. ${ }^{127}$

In light of the above considerations, India has a primary and continuing obligation to act with due diligence to prevent and adequately respond to acid attack violence. Although the Indian government has made progress toward achieving these goals, much work remains to be done. Below we argue that corporations also have a responsibility under the business and human rights framework to act with due diligence to respect and remedy human rights violations, including acid attacks.

\section{Part III: Corporate Accountability for Acid Violence in India}

There is a growing recognition in the international human rights community that transnational corporations have obligations to address and prevent human rights violations. Here, we explain why and how businesses can contribute to reducing acid attacks and the emerging international and domestic laws and norms relating to business and human rights and corporate accountability.

\section{Acid Attacks and Businesses}

Because of the cheap and easy availability of strong acids in harmful quantities in India, companies that produce and sell acid have a significant and positive role to play to limit the unauthorized sale and use of acid and, therefore, to reduce the number of acid attacks in the country. Whether or not perpetrators use acid in ways that were intended by the manufacturers or retailers, businesses that are part of the acid supply chain and that profit from acid sales can and must act to disrupt the negative consequences of their products' use or misuse.

Perpetrators use acid in ways that makers of acid or businesses that use it in their production do not intend, but these corporate entities should still prevent misuse. United States gun manufacturers, for example, are increasingly held to account for individuals' misuse of firearms. On December 14, 2012, a severely mentally ill twentyyear-old man named Adam Lanza opened fire with a Bushmaster AR-15 semiautomatic rifle and massacred 20 first graders and 6 teachers in 5 minutes at the Sandy Hook Elementary School in Newtown, CT (USA). ${ }^{128}$ In 2016, families of the Sandy Hook massacre sued Bushmaster Firearms International and Remington Arms Company to remove the military-style rifle from the civilian market. ${ }^{129}$ The petitioners claimed that the gun manufacturers recklessly sell weapons intended for use in mass killings to civilians and deliberately market such weapons to young civilian males. ${ }^{130}$ Thus, even if

\footnotetext{
${ }^{127} \mathrm{Id}$. at $\S 1(\mathrm{~A})(\mathrm{e})$.

128 James Barron, Nation Reels After Gunman Massacres 20 Children at School in Connecticut, N.Y. TIMES (Dec. 14, 2012), https://www.nytimes.com/2012/12/15/nyregion/shooting-reported-atconnecticut-elementary-school.html.

${ }^{129}$ Donna Soto v. Bushmaster Firearms, No. FBT CV 156048103 S (D. Fairfield filed Oct. 29, 2015), available at

http://civilinquiry.jud.ct.gov/DocumentInquiry/DocumentInquiry.aspx?DocumentNo=9626283. ${ }^{130}$ Id.; Rick Rojas \& Kristin Hussey, Sandy Hook Massacre: Remington and Other Gun Companies Lose Major Ruling Over Liability, N.Y. TIMES (Mar. 14, 2019), https://www.nytimes.com/2019/03/14/nyregion/sandy-hook-supreme-court.html.
} 
not an explicit use of firearms, gun manufacturers may have a duty to prevent and remedy harms resulting from such use. Although acid, unlike firearms, is not something that one naturally assumes can be used to injure and kill people, many people in India including the people who operate the businesses that manufacture and use acid - know that acid is used to perpetrate violence and sell acid with little to no regulation or oversight.

General Electric (GE) is a notable example of a corporation that has recognized its obligations to ensure that business practices and unintentional misuse of products do not lead to international human rights abuses and mass harms. For instance, GE took a number of actions to ensure that ultrasound machines the company sold in India were not used to identify the sex of fetuses to perform illegal sex-selective abortions. ${ }^{131}$ Recognizing that medical professionals were using its ultrasound technology to enable illegal, sex-selective abortions in India, GE instituted a multi-pronged response beyond the actions called for in government legislation, which included: (a) implementing rigorous internal controls; (b) working with the national government and promoting industry best practices; and (c) raising public awareness of female feticide. ${ }^{132}$

Similar to the GE example, acid producers and sellers do not intend for their products to be used to perpetrate acid attacks. Despite acid violence being unintentional misuse of their product, media attention and reporting on acid attacks ${ }^{133}$ put acid producers and sellers on notice that their products must be packaged and handled in a safer manner to avoid misuse. Moreover, even though it may be difficult in India to trace acid from the perpetrator of an acid attack to any particular company, acid producers and sellers can take their market share of the responsibility: the more profit the company makes, the more responsibility the company should take in terms of human rights obligations.

Indeed, companies selling acid and/or operating in India should examine their own roles and relationships in making acid easily accessible. For example, acid is produced and distributed by corporations in enormous quantities, with approximately 200 million tons of sulfuric acid, an acid commonly used in attacks, produced worldwide. ${ }^{134}$ Additionally, local and multinational corporations import acid into these countries. Acids used in attacks are the same used by businesses in manufacturing processes. ${ }^{135} \mathrm{In}$

${ }_{131}$ Michael Cook, GE's Ultrasound Machines and India's Gendercide, BIOEDGE (May 2, 2007), https://www.bioedge.org/bioethics/ges_ultrasound_machines_and_indias_gendercide/6650. $132 \mathrm{Id}$.

133 See, e.g., Arafatul Islam, Why Acid Attacks are on the Rise in India, DW (Aug. 6, 2016), https://www.dw.com/en/why-acid-attacks-are-on-the-rise-in-india/a-19313750; Tanushree Ghosh, Acid Attack in India - Where Does the Nation Stand Today?, HUFFPOST (Mar. 29, 2017), https:// www.huffpost.com/entry/acid-attack-in-india-wher_b_9559790; Kamal Kumar, Acid Attacks: A Scar on India, AlJAZEERA (Jan. 24, 2014), https://www.aljazeera.com/indepth/features/2013/09/acid-attacks-a-scar-india2013927165429393354.html.

134 The Essential Chemical Industry, Sulfuric Acid, http://www.essentialchemicalindustry.org/chemicals/sulfuric-acid.html (last updated Dec. 20, 2013).

135 Law Commission of India Report, supra note 15, at 7. 
India, acid is commonly used in the informal sector to clean toilets, make jewelry and fill car batteries. ${ }^{136}$

Evidence suggests a correlation between legitimate business uses of acid and the incidence of acid attacks. In Bangladesh, for example, the incidence of acid violence is highest in districts where the acid-using garment and jewelry industries are prevalent. 137 Similarly, in Pakistan, acid attacks occur at high rates along the "Cotton Belt" of Pakistan, that is, in Southern Punjab and Upper Sindh (central area), where the cotton and garment industries are concentrated and acid is used in production. ${ }^{138}$ Indeed, acid attackers perpetrated 77\% of all reported attacks in Pakistan's "core" cotton zone areas of the Punjab region. ${ }^{139}$ Additionally, although acid burn incidents have been recorded in 21 different provinces in Cambodia, the largest number of reported incidents $-40.7 \%$ of the total-occurred in Kampong Cham, where most people work with acid on rubber plantations. ${ }^{140}$ Thus, acid is likely easier to access in places where acid-using industries are concentrated.

Given that acid attacks occur at increased rates in areas where acid is widely used for industrial or other business purposes, corporations that produce, distribute, or otherwise use acid should ensure that their activities do not have negative human rights impacts even when governments fail to act. And shareholders, using shareholder proxies, can pressure board members to take action. Companies are in the best position to know their uses and handling of acid and should assess the ways they can reduce their activities' negative human rights impacts. By adopting policies - such as safe handling and labeling of acid, or supply chain accountability - designed to deter intentional acts of violence, companies can also contribute to reducing the number of accidental burns, which is a significant problem in countries like Cambodia. ${ }^{141}$ Finally, all companies that produce, distribute, use, or otherwise handle acid should support industry and government efforts to regulate the safe handling, storage, labeling, transfer and disposal of acid by manufacturers, distributors, other businesses, and individual users of acid in order to deter the unauthorized use of acid.

\footnotetext{
136 Shree Venkatraman, India Needs to Seriously Address its Acid Attack Problem, THE WIRE (Aug. 6, 2016), http://thewire.in/56752/acid-attacks/.

137 See Md. Mahbubul Haque, Impunity and Acid Violence against Women in Bangladesh: Case Studies in Satkhira and Sirajgong Districts, 12 (2005) (unpublished M.A. thesis, Mahidol University), available at http:// mulinet11.li.mahidol.ac.th/thesis/2548/cd383/4737344.pdf. 138 See ACID SURVIVORS FoundATION, PAKISTAN, ACID VIOLENCE IN PAKISTAN: A SITUATIONAL ANALYSIS 13 (Sept. 2015), http:/ / asfpakistan.org/wp-content/uploads/2017/02/SAAV-report-2015.pdf (charting the reported attacks by region and finding the highest prevalence in Multan, Muzaffaragarh, Rahim Yar Khan, Bahawalpur and Lahore); Imran Sharif Chaudhry et al., Economic Analysis of Competing Crops with Special Reference to Cotton Production in Pakistan: The Case of Multan and Bahawalpur Regions, 29 PAK. J. SOC. SCIENCES 51, 52 tbl. 1 (2009) (stating that Bahawalpur, Multan, Muzzafargarh, Lodhran, and Rahimyar Khan regions belongs to the "core" cotton zone of Pakistan). 139 ASF PAKISTAN REPORT, supra note 138, at 13.

140 BREAKING THE SILENCE, supra note 26, at 45 (Phnom Penh, the capital of Cambodia, has recorded the second-highest incidence of acid burns, amounting to $16 \%$ of the total.). ${ }^{141} \mathrm{Id}$.
} 
With mandates to curb acid violence and to remedy victims' harms, we next describe the emerging norms on business obligations to protect human rights.

\section{Business and Human Rights Norms}

The business and human rights regime is nascent and relatively weak given its status as soft law, but the framework is emerging as a promising area for accountability for serious harms incident to business activities globally. When human rights law was first conceived and codified, the primary duty bearers were states parties. In addition, local laws guided corporate standards for respecting human rights. ${ }^{142}$ Today, however, companies measure their conduct against international law, ${ }^{143}$ and, in addition to states parties, the business sector plays a critical role in ensuring the respect for human rights and, specifically, can assist in combating acid violence and its negative consequences.

In 2011, the international and business communities signaled a commitment to respecting and promoting human rights norms when the United Nations Human Rights Council unanimously passed the UN Guiding Principles on Business and Human Rights ("UN Guiding Principles," or "UNGPs"). ${ }^{144}$ The UN Guiding Principles are grounded in international human rights law and state responsibility for respecting, protecting and fulfilling human rights. ${ }^{145}$ The idea is for states to remain the primary duty bearers and to use their coercive powers as well as incentives to promote business respect for human rights within their borders or wherever their companies operate. ${ }^{146}$ In contrast to corporate social responsibility (CSR), a voluntary regime emphasizing responsible behavior, business and human rights (BHR) establishes a core obligation of states and companies to respect human rights, to do no harm, and to remedy any harm caused to victims of human rights abuses. ${ }^{147}$

The UNGPs provide the framework within which BHR operates. Its three pillars are: (1) the state duty to protect against third party human rights abuses; (2) the corporate responsibility to respect human rights; (3) the call on states and companies alike to provide victims of human rights violations with access to effective remedies. ${ }^{148}$ In discharging its BHR responsibilities, companies should adopt human rights policies, conduct human rights impact assessments, and evaluate performance on respecting

\footnotetext{
${ }^{142}$ John Ruggie (Special Representative of the Secretary-General on the issue of human rights and transnational corporations and other business enterprises), Guiding Principles on Business and Human Rights: Implementing the United Nations "Protect, Respect and Remedy" Framework, ๆ 17, U.N. Doc. A/HRC/17/31 (Mar. 21, 2011) [hereinafter UNGPs].

${ }^{143}$ UN Global Compact, 2004 Ten Principles, available at https://www.unglobalcompact.org/AboutTheGC/TheTenPrinciples/index.html.

144 UNGPs, supra note 142.

${ }^{145} \mathrm{Id}$.

$146 \mathrm{Id}$.

147 Anita Ramasastry, Corporate Social Responsibility Versus Business and Human Rights: Bridging the Gap between Responsibility and Accountability, 14 J. HUM. RTS. 237, 238 (2015).

148 UNGPs, supra note 142.
} 
human rights. ${ }^{149}$ With regard to remedies, states must and companies should provide access to judicial, non-judicial and company grievance mechanisms for redress for human rights harms. ${ }^{150}$

Often, in countries in which transnational corporations (TNCs) operate, regulations that would prevent violations of human rights and remedy harms attributable to business practices is lacking or inadequate. ${ }^{151}$ Additionally, governments are either unwilling or unable to remedy business-related human rights harms. ${ }^{152}$ Furthermore, TNCs less frequently directly perpetrate human rights abuses; rather, companies more likely may facilitate or act as accomplices to human rights violations and crimes perpetration. ${ }^{153}$ In many cases, however, corporations are complicit in human rights abuses, or their business activities, including supply chains, contribute to abuses. ${ }^{154}$ Thus, businesses must act to respect human rights and remedy human rights violations when attributable to their activities.

Corporate human rights due diligence obligations respond to these government and business failures to respect and remedy human rights violations. The process assists both states and businesses to identify and prevent human rights abuses, and to provide remedies in the breach. Although admittedly weak in the face of serious corporate harms, corporate engagement to assess the human rights impact of its operations is a positive step forward and a baseline of common principles to follow for companies to adhere to human rights norms. ${ }^{155}$

Business and Human Rights guarantees focus on negative obligations (doing no harm) rather than on positive obligations (doing good and remedying harm) of companies. ${ }^{156}$ Still, implementation of the UNGPs have encouraged states to investigate human rights impact of businesses within their borders. ${ }^{157}$ As a consequence, states are passing laws requiring companies to exercise human rights due diligence and to disclose supply chains policies to prevent human rights violations. ${ }^{158}$ At the same time, the United Nations established a working group to draft a Business and Human Rights treaty

149 Interim Rep. of the Special Representative of the Secretary-General on the Issue of Human Rights and Transnational Corps. and Other Business Enterprises, 19 60-64, U.N. Doc. E/CN.4/2006/97 (Feb. 22, 2006).

150 Surya DEVA, REGULATING CORPORATE HuMAN Rights Violations: HuMANIZING Business 106 (2012) (citing Interim Rep. of the Special Representative of the Secretary-General on the Issue of Human Rights and Transnational Corps. and Other Business Enterprises, supra note 149).

151 Steven R. Ratner, Corporations and Human Rights: A Theory of Legal Responsibility, 111 YALE

L. J., 443, 464 (2001).

$152 \mathrm{Id}$.

$153 \mathrm{Id}$

154 Christie Merino, Why Food Companies Need to Step Up on Human Rights in Global Supply Chains, GREENBIZ (Dec. 19, 2018), https://www.greenbiz.com/article/why-food-companies-need-stephuman-rights-global-supply-chains.

155 See Ramasastry, supra note 147, at 237, 247.

156 Id.

${ }^{157} \mathrm{Id}$.

158 Id. 
toward binding corporate accountability obligations in international law. ${ }^{159}$

Under these norms and obligations, and given the cheap and easy availability of acid to unauthorized users in India, acid producers and suppliers that manufacture or sell acid to Indian markets must also act to ensure that perpetrators of acid attacks are punished and deterred from committing such gender-based crimes.

A positive move toward ensuring that approximately 6000 companies engage in corporate social responsibility (CSR) measures was the enactment of the Companies Act, 2013.160 This Act makes India the first country to mandate CSR by law and adds to the regime of "do no harm" to enhance positive obligations - especially economic, social and cultural rights obligations - of Indian companies, transnational companies and states. ${ }^{161}$

Since 2014, Section 135 of the Companies Act has mandated that private or public companies with a net worth of more than 500 crore INR ( $\$ 100$ million USD), or a turnover of 1000 crore INR ( $\$ 200$ million USD), or a net profit of more than 5 crore INR ( $\sim$ 1 million USD) in the previous year establish a CSR board (Board) with at least three directors and at least one independent director. ${ }^{162}$ The Board must formulate a CSR Policy outlining the activities that the company will undertake as per Schedule VII and monitor such activities. ${ }^{163}$ The Board must ensure that the company spends in every financial year an average of $2 \%$ of its net profits made during the three preceding years on corporate social responsibility activities. ${ }^{164}$ If the company does not spend $2 \%$ of net profits, the Board must give reasons for not meeting its obligations. ${ }^{165}$ Moreover, the Board must preference implementing CSR activities in local communities in which the company operates. ${ }^{166}$

Under Schedule VII, the Act enumerates the CSR activities that fall under the mandate, including eradicating hunger, improving education, protecting the environment, preserving national heritage, and funding humanitarian relief. ${ }^{167}$ For companies that

${ }^{159}$ Human Rights Council Draft Res. A/HRC/26/L.22/Rev.1 (Jun. 25, 2014), https:/ / documentsdds-ny.un.org/doc/UNDOC/LTD/G14/064/48/PDF/G1406448.pdf?OpenElement.

160 Ashok Prasad, India's New CSR Law Sparks Debate Among NGOs and Businesses, THE GUARDIAN (Aug. 11, 2014), available at https:// www.theguardian.com/sustainable-business/india-csr-lawdebate-business-ngo (last visited May 16, 2019).

161 Prasad, supra note 160; PWC, Handbook on Corporate Social Responsibility in India (2013), https:// www.pwc.in/assets/pdfs/publications/2013/handbook-on-corporate-socialresponsibility-in-india.pdf.

162 The Companies Act, No. 18 of 2013, § 135(1), INDIA CODE, available at

http://www.mca.gov.in/Ministry/pdf/CompaniesAct2013.pdf; but see The Companies Act, No. 1 of 2018, INDIA CODE, available at http://www.mca.gov.in/Ministry/pdf/CompaniesAct2013.pdf.

${ }^{163} \mathrm{Id}$.

${ }^{164} \mathrm{Id}$.

$165 \mathrm{Id}$.

$166 \mathrm{Id}$.

167 Prasad, supra note 160. 
produce acid used in acid attacks in India, their obligations under the Companies Act could be used to, among other things: contribute to compensation funds; improve acid sales regulation schemes; and assist with equipment and trainings to ensure proper treatment, rehabilitation and vocational training for victims-survivors. Three specific activities related to acid violence under Schedule VII to which corporations should contribute are: (1) promoting gender equality and empowering women; (2) employment enhancing vocational skills for acid attack victims-survivors; and (3) contributions to government funds, such as those established to assist acid attack victim-survivor medical care and rehabilitation. 168

In addition, in order to reduce the intentional misuse of acid, businesses at different levels can take specific steps beyond those pursuant to the Companies Act. Companies that manufacture and sell acid to markets in India are also under an obligation to act with due diligence to address adverse human rights impacts of their business activities in their places of operation. Additional steps may include the following:

- Companies that distribute acid to individual end-users should ensure that acid containers are labeled to notify users that they contain a dangerous substance and the legal consequences of its misuse.

- Companies that import products manufactured using acid from India should verify that companies within their supply chains follow safe handling, storage, labeling, transfer, and disposal procedures and comply with all existing Indian laws regulating acid sales.

- Companies that produce and distribute acid in India should ensure that their distributors are following safe handling, storage, labeling, transfer, and disposal procedures.

\section{Conclusion}

India's obligation under international law requires that the government exercise due diligence to prevent and adequately respond to acid attack violence as a form of genderbased violence prohibited under CEDAW. In particular, India must act with due diligence to enact and enforce laws combating acid violence; to investigate, prosecute and punish perpetrators; and to redress victims of acid attacks. While India has adopted a statute that heightens criminal penalties on acid attack perpetrators and the Indian Supreme Court has stepped in to mandate the regulation of acid sales, implementation of the acid sale order is lackluster, leading to continued underenforcement of the law, a lack of access to justice for acid violence survivors, and impunity for perpetrators of acid attacks.

In addition to India's obligations, businesses must also take concrete measures to respect human rights and remedy harms, including for acid attacks. Corporations that benefit from the sale and use of acid have important due diligence obligations to do no harm and remedy any harm caused by their business activities. Businesses often produce and use acid in their supply chains and can be the key to regulating its misuse. In today's

168 Id. 
world non-state actors are often as powerful and influential as state actors and, in some cases, the activities non-state actors directly cause or more likely is in the chain of activities that leads to human rights abuses.

Typically, the business and human rights lens is used to address violence against human rights defenders or violations in large-scale development projects or extractive industries, but few have written about the connection between gender violence and business obligations. With the Companies Act, businesses that produce acid or use acid in a significant way in its operations have additional positive obligations to allocate resources to preventing and redressing human rights harms, including acid violence. Moreover, the Companies Act now gives human rights advocates more grounds to push companies to spend their resources on preventing acid attacks and helping survivors rebuild their lives. 